\title{
Exploring the Efficacy of Student Response System in a Sub-Saharan African Country: A Sociocultural Perspective
}

\author{
Alaba Olaoluwakotansibe Agbatogun \\ The Moray House School of Education, \\ The University of Edinburgh, Edinburgh, United Kingdom
}

\section{alabaagbatogun@yahoo.com \\ Executive Summary}

The student response system (SRS) is marketed as a reliable tool for improving students' academic attainment. However, findings to the question of whether or not the SRS does improve the learning outcomes of ESL [English as a Second Language] learners in primary education are not well documented in the research literature. Despite the wide use of English as the medium of communication and instruction in many Anglophone countries such as Nigeria, a teacher's ability to actively engage all students in the classroom is challenging and relatively difficult. Learners' poor performance in school subjects, as well as national examinations conducted by bodies such as the West African Examination Council (W.A.E.C.) and the National Examination Council (N.E.C.O.) has been attributed to teachers' reliance on, and use of, the traditional lecture method which deprives students of the necessary interaction, active engagement and dialogic communication that could promote improved learning outcomes. The adoption, as well as the use, of SRS in schools to enhance teaching and learning is yet to be a reality in Nigeria. Researchers argue that, for learners to experience improved academic attainment, they must possess a reasonable degree of communicative competence in the language of instruction. Moreover, language is best learnt when student learners are given the opportunity to interact in the class with a view of exploring the environmental artifacts to interactively use the target language in real life situations.

Earlier studies have shown that the use of SRS during instructional processes enables meaningful interaction that would facilitate improved educational attainment in the classroom. This study, which explored the sociocultural theory of Vygotsky, was thus conducted to investigate the effectiveness of SRS in English language classrooms with a view to improving the communicative competence of learners. In essence, this study was a quasi-experimental design conducted within 11 weeks, to compare the communicative competence of pupils exposed to SRS and those taught in the traditional classroom. 67 pupils from two Nigerian primary schools constituted the sample of the study. Learners in the traditional lecture method group were exposed to the traditional lec-

Material published as part of this publication, either on-line or in print, is copyrighted by the Informing Science Institute. Permission to make digital or paper copy of part or all of these works for personal or classroom use is granted without fee provided that the copies are not made or distributed for profit or commercial advantage AND that copies 1) bear this notice in full and 2) give the full citation on the first page. It is permissible to abstract these works so long as credit is given. To copy in all other cases or to republish or to post on a server or to redistribute to lists requires specific permission and payment of a fee. Contact Publisher@InformingScience.org to request redistribution permission. ture method. On the other hand, the experimental group experienced peer discussion and active participation in instructional activities as the SRS technology was used to trigger interaction in the classroom at the pre- and post sessions of polling learners' responses by the teacher.

To assess learners' English language communicative competence, a battery of 
English Language Listening Tests and English Language Speaking Tests was used for data collection. Data were analysed at 0.05 significance level via descriptive and inferential statistics (ttests, Analysis of variance, Pearson Product Moment Correlation, and multiple regression). While significant difference was found between the pre-and post-tests of the SRS group, no such significant difference was found within the control group. The results further show that the SRS group outperformed the control group at the post-test stage. Pupils' communicative competence positively and significantly correlated with the listening and speaking skills of pupils in the SRS group. Speaking skill was also found to be potent predictor of pupils' communicative competence in the SRS group.

Keywords: Social interaction, Communication fluency, Pedagogy, Interactive technology.

\section{Introduction}

The student response system (SRS) is marketed as a reliable tool for improving students' academic attainment. However, findings to the question of whether or not the SRS does improve the learning outcomes of ESL learners in primary education are not well documented in the research literature. In the traditional classroom, where lecture methods are adopted, learners' attention span wanes after 20 minutes of passivity during instruction. Passive students would be unlikely to be able to recall more than $25 \%$ of what was taught in the classroom, if the teacher does not promote active learning (Collins, 2007; Meedzan \& Fisher, 2006; Moore, 2007). With the limitations of the conventional lecture method in mind, educators are exploring emerging interactive technologies to facilitate classroom interaction and active learning (Dill, 2008; Duncan, 2006; Meedzan \& Fisher, 2006). Although learners' active engagement and improved learning outcomes through the student response system model (SRS) have been reported, there have been few empirical reports that validate the effectiveness of SRS in the teaching and learning of English as a second language (ESL). The purpose of this study was to assess and compare learners' communicative competence in an ESL classroom environment, based on teachers' adoption of SRS technology, as opposed to learners' performance resulting from being taught by the traditional lecture method.

\section{Literature Review}

Teaching and learning with emerging technologies is globally becoming the order of the day in schools and various institutions of learning. Technology is being used to address the drawbacks inherent in the instructional process (Grimm, Soares, Agrawal, \& Law, 2007; Hall \& Swart, 2007). The current advancement in interactive technologies, coupled with the fall in their cost, is paving the way for increased popularity and adoption of wireless technologies in all levels of the education sector (Draper, Cargill, \& Cutts, 2002). Interactive technologies are highly useful in promoting independent learning as well as the lifelong skills learners require to cope within the information society (Sessoms, 2008). One of the prominent challenges of the traditional classroom is the teacher's inability to create an active learning environment that could improve students' learning outcomes (Mateo, 2010). However, students often find technology-driven instructional processes more fascinating and preferable than teachers' adoption of traditional methods (Rankin \& Hoaas, 2001).

Students' engagement with the lesson content is a key factor to effective teaching and learning (Bachman \& Bachman, 2011). Some of the best indicators of students' active engagement during instructional processes include cooperation, active learning, and prompt feedback from the teacher (Chickering \& Gamson, 1987; National Survey of Students' Engagement, 2006). Ensuring students' active participation, engagement, and interaction in the classroom has been seemingly difficult for lots of teachers to achieve. Tagg (2003) attributes students' passivity in the traditional classroom to the absence of anonymity, to boredom, and to the instructors' inability to identify 
learners' areas of needs. In the traditional classroom, when teachers attempt to find out whether students understand what was taught, students sometimes look at one another without response to the teachers' enquiry. Students' silence in such moments is not a justification of better understanding but rather an indication of fear of expressing their areas of confusion (Duncan, 2006).

Though English is the medium of instruction in Nigerian schools and is the official language of communication in the country, the quality of spoken or written English of many Nigerian students is very poor. The negative effects of the low level of English language proficiency on learning outcomes of Nigerian learners has been attributed to teachers' use and adherence to the traditional lecture method (Ajayi, 2002; Oluwole, 2008). In the traditional language classrooms, learners memorise words and master grammatical rules, rather than being engaged in dialogic communication and interactive sessions. In such situations, learners do not gain the necessary confidence for self-expression because of the fear of committing blunders publicly (Okoro, 2000; Onukaogu, 2002; Yusuf \& Enesi, 2011). Similarly, Adegbile and Alabi (2005) and Ariyo (2010) argue that learners who are communicatively deficient are likely to be academic underachievers. According to Shaver (2010), one of the ways to encourage students' motivation, confidence, and enthusiasm, as well as increase students' academic performance, is to engage them during the instructional process. Marmolejo, Wilder, and Bradley (2004) compared the use of response cards and handraising as indicators of learners' participation in the classroom. Amongst the 27 psychology undergraduate students, it was found that the group of students who used response cards performed better and was more actively engaged in the classroom than their counterparts in the control group who were taught with the lecture method.

Effective teaching implies students leave the class with knowledge they did not bring with them, they can retain what they have learnt, they can apply it to situations in different settings, and they are able to build upon their experience to develop new learning ideas (Lea, 2008). In achieving such robust results during instructional processes learners' exposure to active learning experiences becomes a key factor (Lea, 2008; O'Donoghue \& O'Steen, 2007; Yoder \& Hochever, 2005). The significance of learners' participation in the instructional process is further exemplified in Dale's (1969) learning pyramid (Figure 1).

Dale's Learning Pyramid illustrates that the traditional lecture method is the least effective means

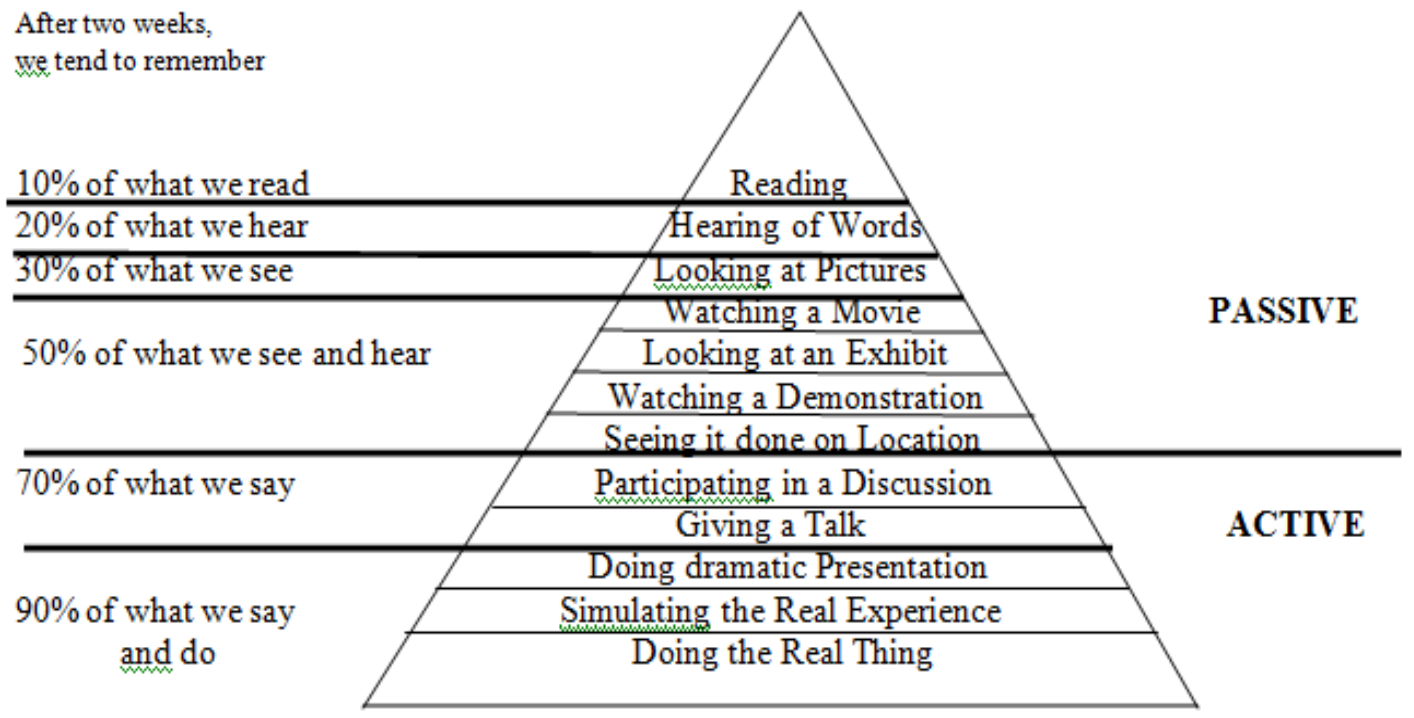

Figure 1

Edgar Dale's Leaming Pyramid(1969) 
of promoting learning because the method provides learners with not more than a $50 \%$ retention rate, whereas participation in a classroom discussion as well as classroom interaction, gives learners access to between $70 \%$ and $90 \%$ retention rate. The pyramid is suggestive of the fact that learners gain most when they are actively engaged in classroom activities because then they are more motivated to learn. Earlier research findings show that active learning lends itself to enhanced learning outcomes (Freeman \& Herron, 2007; Knight \& Wood, 2005). Active learning emphasises interaction between the teacher and learners, as well as among learners. There has been a global paradigm shift from traditional teaching methods to interactive pedagogy that would trigger meaningful learning, problem solving, and the development of critical thinking (Boyer, 1998; Bransford, Brown \& Cocking, 2000; O’Donoghue \& O’Steen, 2007). Initiating and sustaining interactivity in the classroom has been a challenge to many educators (Ulbig \& Notman, 2010). Moreover, many students do not have the exciting experiences expected in the new age of knowledge development. Other methods (use of flash cards, group discussion, and raising of hands), explored by some teachers as alternatives to the use of emerging interactive technologies to generate classroom interactivity, have been criticised for their various limitations (Lea, 2008; Ribbens, 2007). Stowell and Nelson (2007) investigated the benefits of SRS on 140 psychology undergraduates' learning outcomes in a university in the United States of America. The researchers reported that students who were exposed to the interactive technology outperformed their counterparts in the 'response cards' and 'traditional lecture' groups.

To foster useful interaction in the classroom, there has been much global reliance on the potential of new technologies (Mollborn \& Hoekstra, 2010). For instance, the research finding of Hall and Swart (2007) reveals that, among 112 students of Psychology and Operational Management in a business course, students in the wireless polling device group were more comfortable asking questions, had focused attention, and participated more actively in class than the students in the traditional classroom. To further corroborate this, Swan, Kratcoski, Schenker, and van 'tHooft (2010) found that, among grade 3 - 8 school students in a small district of Northern Ohio, United States, students of language arts who were exposed to teaching with frequent use of an Interactive Whiteboard (IWB) were more creative, constructive, and performed better than students whose teacher did not effectively employ the IWB to enhance classroom interaction. Besides the use of IWB and some mobile technologies, a number of researchers (Camey, Gray, \& Wert-Gray, 2008; K. Johnson \& Lillis, 2010; O'Donoghue \& O'Steen, 2007) posit that one of the "hot" technological tools which provide solutions to the challenges in the traditional classroom is the Students Response System (SRS).

The Student Response System (SRS) is one of the productive alternative pedagogies that educators can access to ensure learners' engagement in critical thinking and active participation during instructional processes (Crouch \& Mazur, 2001; Mintzes \& Leonard, 2006). The SRS is a wireless interactive handset that collates and projects students' (anonymous) responses to a teacher's questions. A receiver (dongle) attached to the Universal Serial Bus (USB) of the teacher's computer recognises and captures students' responses from the individual handsets. The recorded data are automatically displayed on the projection screen. The class can then discuss and possible reattempt the questions (M. Johnson \& Robson, 2008; Marlow, Wash, Chapman, \& Dale, 2009; Surgenor, 2010). Though SRS technology has been available since the early 1970s, its adoption and popularity in the educational mainstream has begun only relatively recently, as the SRS technology has become affordable to institutions, teachers and students, as well as its ease of use having improved (Marlow et al., 2009). The use of SRS has also been extended from sciences to other school subjects and academic disciplines (Hancock, 2010; Mareno, Bremmer, \& Emerson, 2010). To effectively prompt interaction and peer instruction in the classroom through SRS, Fagen, Crouch, and Mazur (2002) and K. Johnson and Lillis (2010) suggest that: 
- At the beginning, during or at the end of the lesson, the teacher displays pre-prepared PowerPoint slide question(s)

- Students respond through the wireless SRS keypads

- Teacher prompts group interaction or peer discussion after the display of responses with no clue to the correct answer

- Students respond a second time through the keypads

- Correct answers are indicated, followed by the teacher's explanation, comments and contributions.

Adopting SRS in the classroom provides teachers with the opportunity to measure learners' prior knowledge, determine whether students have completed assigned reading, test students' conceptual understanding, and facilitate class or peer discussion (Lea, 2008). Cain and Robinson (2008) assert that the integration of SRS in instructional processes fosters a higher level of interaction. Similarly, Hoffman and Goodwin (2006) and Martyn (2007) emphasise that the use of SRS trig-

gers increased interaction in the classroom. The "game approach" features of SRS technology and the fun it adds to the instructional process also enhance the creation of an enabling learning environment. According to Wood (2004), an easy way of measuring students' understanding and learning needs is through the teacher's use of SRS. Bergtrom (2006: p. 106) summarised the pedagogical advantages of student response systems as:

- Increased learners' participation

- Better formative assessment of students' learning

- Instant feedback on students' retention and learning to both students and instructor

- Involving all students in critical thinking exercises

- Increased opportunities for student-student interaction

- Increased opportunity for student-lecturer interaction in the class

- Increased student attention and awareness in the class

- More lively engagement of students

- Improved attendance

To date, substantial empirical data from earlier research have also identified the remarkable effects of SRS in the classroom. M. Johnson, Robson, and van Scyoc (2007) report that a larger percentage of students claimed that the use of SRS in the class enabled them to pay more attention and receive more timely feedback. Similarly, the results of a survey conducted by Mateo (2010) on 290 students of the University of Manitoba who were enrolled in a Basic Statistical Analysis course revealed that over $71 \%$ of the students agreed that teacher's adoption SRS during instruction motivated their increased attendance in the classroom. Moreover, $61 \%$ of the students also found SRS to be a very helpful learning tool in the class. Almost $50 \%$ of the students were comfortable recommending SRS to their friends, and a majority of the students concurred that the technology improved their interest in the class. In a case study, SRS was introduced to prompt the critical thinking of 46 final year Accounting and Finance undergraduates at the Dublin Institute of Technology. Morales's (2011) report of the study showed that SRS was considered as the best alternative to the traditional lecture-method classroom, as it provided a more relaxed and less apprehensive learning environment to the students.

\section{Statement of the Problem}

A number of researchers have reported how the use of SRS has been beneficial to the teacher and the students (Caldwell, 2007; Kennedy \& Cutts, 2005; Latessa \& Mouw, 2005; Schackow, Chavez, Loya, \& Friedman, 2004). However, most of these studies were descriptively conducted and carried out in developed countries. Despite the general outcry about Nigerian students' poor performance in school subjects, at least in part, due to their low level of communicative compe- 
tence in English, the use of SRS to enhance the quality of teaching and learning in Nigerian schools is yet to be explored. Furthermore, there is a dearth of research on the effectiveness of the use of SRS in the ESL classroom in Nigeria. The goal of this current research was to address that gap by studying the efficacy of SRS in improving pupils' academic performance in an ESL classroom with respect to their communicative competence in English.

\section{Theoretical Framework}

Vygotsky's sociocultural theory forms the theoretical framework for this research. A sociocultural perspective describes knowledge as that which exists within the interdependence of society's members and the artifacts society creates. In other words, a child learns as he/she engages in social activities. Continuous practice of activities integrates the child into the membership of the society (Phan, 2009). Social interaction through the zone of proximal development (ZPD) is a key component of effective learning because learning is perceived as being a socially, historically, and culturally integrated concept (Vygotsky, 1986, 1993). Vygotsky (1978) thus propose the ZPD as:

The distance between the actual developmental level as determined by independent problem solving and the level of potential problem solving as determined through problem solving under adult guidance or in collaboration with more capable peers ... The zone of proximal development defines the functions that have not yet matured but are in the process of maturation, functions that will mature tomorrow but are currently in embryonic state. These functions could be termed the "buds" or "flowers" of development rather than the "fruits" of development. The actual development level characterizes mental development retrospectively, while the zone of proximal development characterizes mental development prospectively. (p. 86)

The point of ZPD becomes the point of paradigm shift, because what the child could do with the assistance of more knowledgeable people might be more indicative of the child's mental development than what the child can achieve on his own (Cook, 2010). The major emphasis of Vygotsky's socio-cultural theory in education is the significance of a child's interaction with more knowledgeable people and peers in his environment. As the child interacts, he or she socially and culturally co-constructs knowledge in the community and internalises it (Turuk, 2008). Learning is mediated through language generated within the environment (Lantolf, 2000; Le, 2003). Pedagogically, the teacher should develop social teaching behaviours that promote assistedperformance in the class. In other words, interaction and discourse in social contexts between the teacher and the students, as well as among students, are useful means of achieving effective teaching and learning.

\section{Research Hypotheses}

Four hypotheses and a research question were raised for the study:

- That the communicative competence pre-test and the post-test mean scores for the SRS group would be significantly different.

- That the communicative competence pre-test and the post-test mean scores for the control group would be significantly different.

- That the SRS group would have significantly higher communicative competence post-test mean score than the control group.

- That the relationship between the communicative competence and the listening skills, as well as the speaking skills, of pupils in the SRS group would be significant.

- Research Question: What are the relative and joint contributions of listening and speaking skills to the communicative competence level of pupils in the SRS group? 


\section{Method}

\section{Design}

A quasi-experimental pre-test post-test non-equivalent control group design was used to explore the dependence of communicative competence pre-test and post-test scores of two groups of pupils. The two groups of pupils were the SRS technology group (exposed to the Students Response System during instructional process) and the control group (taught with the traditional lecture method).

\section{Participants}

The population of this research, from which the research sample was selected, was all the educationally disadvantaged primary six pupils (aged between 10 and 13 years) in all primary schools in Ijebu-North Local Government (INLG), Ogun State, Nigeria. The study explored a multi-stage sampling technique for sample selection. All schools in the local government area were initially stratified into educationally advantaged and disadvantaged. Thereafter, two educationally disadvantaged schools (located in the sub-urban areas) were selected based on the convenience sampling method. Without prejudice, the schools were assigned to control and experimental groups.

The sample of this study was 67 pupils $($ Male $=29$, Female $=38)$ from two schools $(A=S R S$ group, $\mathrm{B}=$ control group). In the SRS group, there were 41 pupils (Male $=14$, Female $=27$ ), while there were 26 pupils (Male $=15$, Female $=11$ ) in the control group. The average age for the pupils in the SRS group was 11.5, while that of the control group was 12. Generally, the average age and the standard deviation for all the participants was 11.53 and .84 .

\section{Instruments}

In order to assess pupils' communicative competence, test scores in listening and speaking skills were used. Communicative competence in this study refers to learners' ability to use English appropriately, while interacting with other people in an attempt to exchange messages. Safranj (2009) and Canary and Cody (2000) remark that communicative competence is measured by the degree at which the goals of interaction are achieved with the interlocutors' appropriate use of the target language in communication. English Language Listening Tests and English Language Speaking Tests were therefore developed to measure pupils' communicative competence. The developed items were based on the content of the Macmillan New Primary English Book Six (the English textbook used in the study's context). The items of the instruments were generated by the researcher in collaboration with seven primary-school English-language teachers. All instruments used in the study were subjected to pilot-testing carried out on a pilot-sample of the population that was different from the sample that was involved in the main study.

The two classes from different schools involved in the piloting were randomly assigned to different treatment conditions. The instruments were first administered in both schools between Monday and Thursday. The administration of the instruments was done in such a way that the English Language Listening Tests 1, 2, 3 and 4 were administered in the morning of each day. The English Language Speaking Tests 1 and 2 were administered in the afternoon of every other day in each school. The procedure for the administration of the instruments arrangement was done in this way in order to reduce test-boredom and stress on the part of the pupils and teachers respectively. The English Language Speaking Tests and English Language Listening Tests were administered the second time with a two-week time gap between the first and second administrations. Thereafter, classical item analysis was also performed by computing the difficulty and discrimination indices of all items in each instrument. 
After the pilot study, some modifications were made to some instruments. For instance, the word "jot" contained in the instruction to pupils in English Language Listening Tests was replaced with "write". The results of the classical item analysis showed that all but two items of the English Language Speaking Test 2 had item difficulty indices that ranged between 0.4 and 0.8 , as well as discrimination indices that were above 0.3 . In line with the acceptable rule of thumb; when an item's difficulty is below 0.3 , it is considered a difficult item, and an item with a discrimination index above 0.8 is considered to be too easy; "How do you want to spend the next weekend?"'(pi $=0.3, \mathrm{Di}=0.97$ ) and a pictorial illustration from the English textbook meant to be described by the pupils based on the question "what is the child doing?" $(\mathrm{Pi}=0.34, \mathrm{Di}=0.92)$ were removed from further use in the study.

\section{English Language Listening Tests}

To assess pupils' listening ability, English Language Listening Tests (ELLTs) 1, 2, 3 and 4 were administered in the study. Each test comprised of a short comprehension passage and five short questions. The comprehension passages were summaries of selected comprehension passages contained in the pupils' English textbook. Some of the multiple-choice questions for the passages in the textbook were changed into short answer questions and sentence completion questions. Each question attracted a maximum of 3 marks, but pupils' responses with minor spelling errors received partial marks from 1 to less than 2.5 marks for the test item.

Teachers administered the tests based on the teacher's guide prepared by the researcher. Items of the teacher's guide included "pupils should be first allowed to individually read the questions", "teacher to read the text at the first instance while the pupils listen for comprehension", "teacher to read the text to the pupils at the second instance to identify the needed information/answers". The teacher's guide also included "teacher pauses in between each question for a maximum of 90 seconds to allow pupils to write down their answers", "teacher's reading speed should not be too fast," and "where need be, the instructions can be interpreted/read to the learners in their first language". The test re-test reliability scores of English Language Listening Tests 1, 2, 3 and 4 were $.94, .93, .86$ and .87 respectively.

\section{English Language Speaking Tests}

There were two English Language Speaking Tests administered in this study. The English Language Speaking Tests (ELSTs) 1 and 2 were used to assess pupils' English speaking ability. The English Language Speaking Test 1 consisted of ten items (nine mini-guided-situations and one picture-description test items). Likewise, the English Language Speaking Test 2 comprised of eight items (seven mini-guided-situations and one picture-description test items). All items of the English Language Speaking Tests 1 and 2 were generated to prompt pupils' use of the target language in real life situations. Selected vocabulary, comprehension passages, and structure exercises in the pupils' English textbook were changed into sentences that reflect guided real-life situations which required pupils' responses. Moreover, the two pictures presented to the pupils for them to describe were also from different comprehension passages in the pupils' English textbook. Testing the pupils' speaking skills was in the form of one-to-one interviews. As the teacher read each of the items to the individual pupil in question form, each pupil was expected to respond to the teacher within a frame of 90 seconds per item.

The test was administered by the teachers based on the guide developed by the researcher. Items from the teacher's guide included "teacher should explain the purpose of the test to the pupils; an attempt to test their speaking ability", "teacher should ask the pupils to be confident and be expressive as much as they can". The teacher's guide also states that "teacher should conduct the test on individual basis while much effort should be made to ensure confidentiality while conducting the test". Pupils' performances in each item were rated on a scale of 0 to $5(\mathbf{0}=$ No Response, 
$\mathbf{1}=$ Very Poor, $\mathbf{2}=$ Poor, $\mathbf{3}=$ Fair, $\mathbf{4}=$ Good and $\mathbf{5}=$ Very Good). The test re-test reliability of English Language Speaking Tests 1 and 2 were .87 and .88 respectively.

A sample of 12 copies of pupils' listening and speaking scripts were subjected to double blind review by an independent rater and the teacher to each group. The inter-rater reliability coefficient of the raters' judgement was .99. The range of possible achievable scores for the listening test was from 0 to 60, and speaking test ranged between 0 and 90 . For the overall communicative competence, the range of possible values was from 0 to 150 . Obtained marks in all the listening and the speaking test items were summed up to estimate the total communicative competence score for each pupil. Scores above 59 indicate high communicative competence and scores below 58 indicate low communicative competence.

\section{Validity of Instruments}

The instruments used in this study were subjected to rigorous review by a review-committee constituted by the researcher (seven English language teachers), two experts in e-learning, one quantitative researcher, and two English language lecturers. Having given due consideration to the comments of the reviewers, the final versions of the instruments were produced.

\section{Equipment}

The equipment used for this study was a 48- piece Radio Frequency mode of Students Response System of eInstruction.

\section{Procedure}

The approval to conduct the study in the selected schools was granted by the Executive Secretary and the Education Officer of Ijebu North Local Government Education Authority, as well as the various head-teachers of the schools. With the assistance of the head-teachers, the target pupils were given a consent form which provided all details about the intended research for their parents to complete. Parents had the opportunity on the form to decline their child's or ward's participation in the research, while opportunity was also given to withdraw him or her at any point without any penalty. The researcher and two research assistants collected all data between September, 2010 and April, 2011. In the first week of the research, introduction of the research purpose to the pupils and the administration of the pre-test to assess the existing language proficiency level of the pupils were carried out. The post-test was administered at the eleventh week to determine pupils' gains with respect to English language proficiency. Throughout the period of the research, pupils across the groups were taken through the same content in oral and written comprehension, composition, and grammar activities carefully and unanimously selected by their teachers.

In the SRS group, the data projection system was always arranged in the class by the teacher and the trained research assistants during the English language lessons. The laptop computer was set at the back of the class where the research assistants could easily assist the English teacher to project questions on the projection screen without distracting the pupils. In the first week, the basic procedure of the use of the technology in anonymous mode was practised with the pupils, before its continued daily use during English lessons. The teacher assigned communicative tasks relevant to the topic and the content of the textbook to pupils in pairs or groups. Based on the classroom exercises in the English language textbook, the teacher framed and posed between 2 and 3 questions either at the beginning, during, or towards the end of the lessons.

In each lesson, the teacher and the research assistants distributed the SRS handsets to the pupils at the beginning and collected them at the end of the class. To use SRS, the teacher displayed the questions on the projection screen while pupils were allowed to work out the possible answer and send their responses within a time frame of 30 seconds. Pupils' responses were displayed on the 
projection screen at first, without the correct answer being revealed. Thereafter, the teacher asked the pupils to discuss and argue out their opinions with their peers. After the discussion, pupils were given a second chance to re-submit their responses using SRS. The teacher displayed the responses together with the correct answer. Afterwards, the teacher summarised the discussion and further explained the reasons why some options were not the correct answer. More often, the distribution of pupils' responses in the second voting attempts were much better that in the first instances. Pair work was blended with the use of SRS in order to provide pupils the opportunity to talk at their own pace with peers, use the target language freely without pressure, and increase the amount of practice. Moreover, it was also intended that pupils would have access to cooperative and collaborative language learning, increased talk time, and opportunity to clarify issues among themselves. Similarly, the strategy discourages pupils from relying on short answers to questions. Rather pupils are provided the opportunity to achieve success in communication as they talk with peers.

There was a control group set up in the study. In the control group, the lecture method of teaching and learning was used by the teacher. In essence, the teacher dominated classroom activities throughout the lesson, from the introduction through presentation and summary. Rather than assign communicative tasks, the teacher rarely asked questions that would prompt pupils' critical thinking. The teacher randomly called a few pupils who raised their hands to indicate their willingness and readiness to answer questions. Towards the end of the lessons, the teacher instructed the pupils to write the answers to the textbook activities in their notebooks and submit them for marking.

\section{Data Analysis}

In order to determine whether significant differences existed within groups and between groups with reference to the relevant hypotheses, paired samples t-test and independent t-test statistics were respectively conducted. Pearson Product Moment Correlation was also performed to find the correlation between communicative competence and listening skills, as well as the speaking skills, for the SRS group. Multiple regression analysis was also undertaken to predict the contributions of listening and speaking skills to the prediction of the communicative competence of pupils in the SRS group. Descriptive statistics of the data were also presented.

\section{Results}

\section{Hypothesis 1}

The communicative competence pre-test and the post-test mean scores for the SRS group would be significantly different.

Table 1: Descriptive Statistics of SRS Group's Communicative Competence Pre-test and Post-test Scores

\begin{tabular}{lccccc}
\hline & N & Min. & Max. & Mean & SD \\
\hline Comm. Competence Pre-test Scores & 41 & 19.00 & 112.00 & 61.22 & 24.35 \\
Comm. Competence Post-test Scores & 41 & 54.00 & 128.00 & 88.12 & 17.53 \\
\hline
\end{tabular}

Table 1 presents SRS's communicative competence pre-test and post-test scores. The average communicative competence pre-test score (61.22) for SRS's group was lower than the average communicative competence post-test score (88.12). Similarly, the minimum communicative competence pre-test score (19.00) and maximum communicative competence pre-test score(x) (112.00) were lower than the minimum communicative competence post-test (54.00) and maximum communicative competence post-test scores (128.00). In order to determine whether there 
was any significant difference between the communicative competence pre- and post-test mean scores for the group, data were subjected to paired samples t-test analysis and the results are presented below:

Table 2: $t$-test Comparison of Students Response System Group's Pre-test and Post-test Scores

\begin{tabular}{lcccccl}
\hline & $\mathrm{N}$ & Mean & SD & Df & T & Sig. \\
\hline Comm. Competence Pre-test & 41 & 61.2 & 24.3 & 41 & -11.232 & $\mathrm{p}<.05$ \\
Comm. Competence Post-test & 41 & 88.1 & 17.5 & & & \\
\hline
\end{tabular}

Table 2 presents the results of the paired samples t-test comparison of communicative competence pre-test and post-test scores of the SRS's group. The results show that a significant difference $\left(\mathrm{t}_{(41)}=-11.232, \mathrm{p}<.05\right)$ exists between the pre-test scores $(\mathrm{M}=61.2, \mathrm{SD}=24.3)$ and the post-test scores $(\mathrm{M}=88.1, \mathrm{SD}=17.5)$ of SRS group. The results indicate that pupils in the SRS's group had improved communicative competence, as indicated by scores achieved in the post-test. Such results imply that pupils in ESL classrooms would have improved communicative skills if they are taught with SRS technology. The hypothesis which states that "that the communicative competence pre-test and the post-test mean scores for the SRS group would be significantly different" was accepted.

\section{Hypothesis 2}

The communicative competence pre-test and the post-test mean scores for the control group would be significantly different.

Table 3: Descriptive Statistics of Control Group's Communicative Competence Pre-test and Post-test Scores

\begin{tabular}{lccccc}
\hline \multicolumn{1}{c}{ Type of Test } & N & Min. & \multicolumn{1}{c}{ Max. } & Mean & SD \\
\hline Comm. Competence Pre-test Scores & 26 & 29.00 & 102.00 & 67.85 & 21.36 \\
Comm. Competence Post-test Scores & 26 & 31.00 & 84.00 & 63.77 & 16.96 \\
\hline
\end{tabular}

The results in Table 3 show the communicative competence pre-test and post-test mean scores for pupils in the control group. The results indicate that the average communicative competence pretest score (67.85) was higher than the communicative competence post-test average score (63.77) for pupils in the control group. Furthermore, the minimum communicative competence pre-test score (29.00) was lower than the minimum communicative competence post-test score (31.00), the maximum communicative competence pre-test score (102.00) was higher than the maximum communicative competence post-test score (84.00) score.

Table 4: $t$-test Comparison of Control Group's Communicative Competence Pre-test and Post-test Scores

\begin{tabular}{ccccccl}
\hline & $\mathrm{N}$ & Mean & SD & Df & T & Sig. \\
\hline Comm. Competence Pre-test & 26 & 67.8 & 21.4 & 25 & .991 & $\mathrm{p}>.05$ \\
Comm. Competence Post-test & 26 & 63.8 & 17.0 & & & \\
\hline
\end{tabular}

Table 4 shows the paired samples t-test results of the comparison of communicative competence pre-test and post-test scores of pupils in the control group. The results reveal no statistically significant difference $\left(\mathrm{t}_{(25)}=.991, \mathrm{p}>.05\right)$ between the communicative competence pre-test scores $(\mathrm{M}=67.8, \mathrm{SD}=21.4)$ and the post-test scores $(\mathrm{M}=63.8, \mathrm{SD}=17.0)$ for pupils in the control 
group. In other words, pupils in the control group had very similar communicative competence pre-test and post-test mean scores. The implication of the results is a show of evidence that there may be no improvement over the time scale of these observations in the communicative competence of pupils in an ESL classroom if taught with the traditional methods. The hypothesis which states that "the communicative competence pre-test and the post-test mean scores for the control group would be significantly different" was rejected.

\section{Hypothesis 3}

The SRS group would have a significantly higher communicative competence post-test mean score than the control group.

Table 5: $t$-test Comparison of Pupils' Communicative Competence Post-test Scores between Groups

\begin{tabular}{lllcccl}
\hline Group & $\mathrm{N}$ & Mean & SD & df & T & Sig. \\
\hline SRS & 41 & 88.12 & 17.54 & 65 & 5.609 & .0001 \\
Control Group & 26 & 63.77 & 16.97 & & & \\
\hline
\end{tabular}

The results in Table 5 present the independent t-test results of the comparison of communicative competence post-test scores of pupils in the SRS and control groups. The results indicate a statistically significant difference $\left(\mathrm{t}_{(65)}=.5 .609, \mathrm{p}=.<.05\right)$ between the communicative competence post-test scores $(\mathrm{M}=88.12, \mathrm{SD}=17.54)$ of the $\mathrm{SRS}$ group and the communicative approach posttest scores $(\mathrm{M}=63.77, \mathrm{SD}=16.97)$ of the control group. The results thus suggest that pupils in the SRS group recorded improved communicative competence compared to those in the control group. From all indications, the finding of this study present sufficient evidence to claim that pupils' communicative competence would be better improved if they are taught English as a second language (ESL) with the SRS. Therefore, the hypothesis which states that "the SRS group would have significantly higher communicative competence post-test mean score than the control group" was accepted.

\section{Hypothesis 4}

The relationship between the communicative competence and the listening skills as well as the speaking skills of pupils in the SRS group would be significant.

Table 6: Descriptive Statistics of SRS Group's Communicative Competence Skills

\begin{tabular}{llcr}
\hline & N & Mean & \multicolumn{1}{c}{ SD } \\
\hline Comm. Competence & 41 & 88.12 & 17.54 \\
Listening Skills & 41 & 64.15 & 9.48 \\
Speaking Skills & 41 & 85.20 & 35.79 \\
\hline
\end{tabular}

The results in Table 6 show the means and standard deviations of the SRS group's communicative competence, listening skills and speaking skills. The results reveal that in the SRS group, the scores of their communicative competence were (Mean $=88.12, \mathrm{SD}=17.54$ ), while their listening skills scores were $(\mathrm{Mean}=64.15, \mathrm{SD}=9.48)$ and the scores for their speaking skills were $($ Mean $=85.20, \mathrm{SD}=35.79)$. 
Table 7: Correlations Matrix of Communicative Competence, Listening Skills and Speaking Skills for the Students Response System Group.

\begin{tabular}{lccc}
\hline & $\begin{array}{c}\text { Comm. } \\
\text { Competence }\end{array}$ & $\begin{array}{c}\text { Listening } \\
\text { Skills }\end{array}$ & $\begin{array}{c}\text { Speaking } \\
\text { Skills }\end{array}$ \\
\hline Comm. Competence & & & \\
Listening Skills & $.490^{*}$ & & $.287^{*}$ \\
Speaking Skills & $.890^{*}$ & & \\
\hline
\end{tabular}

Table 7 presents the Pearson Product Moment Correlation results of the relationship between the communicative competence and the listening skills, as well as the speaking skills, of the SRS group. The results indicate a statistically significant and positive relationship between the SRS group's communicative competence and listening skills (.490). Similarly, a positive and significant correlation exists between communicative competence and the speaking skills (.890) of pupils in the SRS group. The results suggest that as the group's listening and speaking skills increase, communicative competence also increases. The results further reveal a significant and positive relationship (.287) between the listening skills and speaking skills of pupils in the group. The implication of the results is that pupils who experience improved levels of listening skills are likely to have corresponding improvement in speaking skills when exposed to the use of SRS in an ESL classroom. Based on the finding of this study, the hypothesis was accepted.

\section{Research Question 1}

What are the relative and joint contributions of listening and speaking skills to the communicative competence level of pupils in the SRS group?

Table 8: Model Summary, Coefficient and t-value of Multiple Regression Analysis of the Predictor Variables and the Outcome measure

\begin{tabular}{|c|c|c|c|c|c|}
\hline \multirow[b]{2}{*}{ Model } & \multicolumn{2}{|c|}{$\begin{array}{l}\text { Unstandardized Coef- } \\
\text { ficients }\end{array}$} & \multirow{2}{*}{$\begin{array}{l}\text { Standardized } \\
\text { Coefficients } \\
\text { Beta }\end{array}$} & \multirow[b]{2}{*}{$\mathrm{t}$} & \multirow[b]{2}{*}{ Sig. } \\
\hline & B & Std. Error & & & \\
\hline 1 (Constant) & 23.630 & 7.494 & & 3.15 & .003 \\
\hline Listening Skills & .474 & .120 & .256 & 3.94 & .000 \\
\hline Speaking Skills & .400 & .032 & .816 & 12.55 & .000 \\
\hline \multicolumn{6}{|l|}{ Model Summary } \\
\hline \multicolumn{6}{|c|}{ Multiple $\mathrm{R}^{2}=.852$} \\
\hline \multicolumn{6}{|c|}{ Multiple $\mathrm{R}^{2}$ (Adjusted) $=.845$} \\
\hline \multicolumn{6}{|c|}{ Std. Error Estimate $=6.916$} \\
\hline \multicolumn{6}{|l|}{$\mathrm{F}=109.62$} \\
\hline Sig. $=.001$ & & & & & \\
\hline
\end{tabular}

Dependent Variable: Post-communicative competence

$\mathrm{P}=<.05$

The results in Table 8 show that both listening and speaking skills combined to contribute a coefficient of multiple regression of .845 and a multiple correlation square of .852 to the prediction of SRS group's communicative competence level. The results thus indicate that $85.2 \%$ of the total variance of the communicative competence of the SRS group was accounted for by the combina- 
tion of their listening and speaking skills. The results further show that the analysis of variance of the multiple regression data produced an F-ratio value significant at 0.05 level $\left(\mathrm{F}_{(2,38)}=109.62 ; \mathrm{p}\right.$ $=.0001)$. Furthermore, with respect to the relative relevance of listening and speaking skills to determining pupils' communicative competence in ESL classroom, the results reveal that speaking skills $(\beta=.816, \mathrm{t}=12.55, \mathrm{p}=.001)$ contributed more than the listening skills $(\beta=.256, \mathrm{t}=$ $3.94, \mathrm{p}=.001)$ to the prediction of pupils' communicative competence in ESL classroom.

\section{Discussion}

This study set out to investigate the effectiveness of SRS in improving the communicative competence of learners in ESL classrooms. The results of this study clearly demonstrate that, with respect to communicative competence in English language, there was a significant improvement between the pre-test and the post-test scores among pupils in the SRS group. However, research finding of Hudson, McGowan, and Smith (2011), which indicates that the post-test scores of pupils in the SRS group were lower than the pre-test scores, is at variance with the outcome of this study. Findings of this study corroborate the research results reported by Petersohn (2008), Reay, $\mathrm{Li}$, and Bao (2008) and Crouch and Mazur (2001). Furthermore, the outcome of this study may provide evidence to show that teachers are beginning to realize that interactive technology, like SRS, provides opportunity for learners' interaction, active engagement, and improved learning outcomes.

That the pre- and post-tests results of this study reveal no improvement in the English communicative competence of pupils who were taught with the lecture method is not surprising. Traditional classrooms are teacher-dominated with passive learners. It is more of a reality than a myth that learners gain more when they are actively engaged in instructional activities. However, in contradiction with the outcome of this study, earlier researchers (Hudson et al., 2011; Petersohn, 2008) indicated that there was significant improvement from the pre-test to the post-test performance of pupils in the traditional classroom.

That the post-test communicative competence level of the pupils in the SRS group was better than those in the traditional classroom is consistent with the revelations of Reay, Li, and Bao (2008), Holderied (2011) and Petersohn (2008), which indicated that the post-test performance of students who were exposed to clickers was above those in the control group. However, Patterson, Kilpatrick, and Woebkenberg (2010) reported no significant difference in the post-test performance of learners in the SRS and non-SRS groups. Also at variance with the outcome of this study, Hudson, McGowan, and Smith's (2011) study which investigated the efficacy of SRS in enhancing students' motivation and learning gains in library instruction revealed that students with pretest- and post-test paper format and those with post-test paper format modes of assessment outperformed students in the SRS group on the post-test.

The outcome of this study may have been informed by several issues. At first, working in pairs or groups might have provided pupils the opportunity to practice the use of the target language in real-life situations. Naturally, students would be more willing to express themselves where there is no interference or undue pressure from the teacher. It should also be noted that the more children use a language in oral communication, the more confident they are likely to be in exchanging ideas and information in the language with other people. Moreover, access to unhindered expression and self-correction of errors and/or peer error correction in a language class, encourages the continued use of the language and improved competence in its use. Perhaps the SRS group's improved communicative competence might also be because learners had the opportunity to discuss their opinions, ideas, and answers with their classmates.

It is interesting to note the linear relationship between the communicative competence and the language skills (listening and speaking) of pupils in the SRS group. In the SRS group, the pupils 
had the opportunity to negotiate meaning during discussion. Furthermore, since competence in the use of a language is best developed where there is ample opportunity to use the language, SRS was therefore used to break the ice as pupils discussed among themselves in the classroom. Students tend to collaboratively correct their mistakes and overcome the problem of speech anxiety when they discuss and interact together in a language classroom. Besides, students also gain more confidence to use the language gradually, frequently, and appropriately. Lending support to this outcome, Uso-Juan and Martines-Flor (2008) posit that dialogic and interactive activities in the classroom help to develop students' listening and speaking skills. Powers (2010) confirms that the basic language skills (listening, speaking, reading, and writing) are complimentarily related. Individuals, therefore, need to develop their language skills in order to communicate effectively.

Moreover, listening and speaking skills combined to contribute $85.2 \%$ to the prediction of pupils' communicative competence in an ESL classroom. The finding of this study indicates that the strength of the joint predictive independent variables is relevant and significant to the prediction of the SRS group's communicative competence in an ESL classroom. Furthermore, this study reveals that speaking skills are a potent predictor of pupils' English language communicative competence. Laying emphasis on the importance of speaking ability in language fluency, Gumpez (2001) cited in Kamiya (2006) argues that, in the process of conversation, interlocutors attain communicative goals through real-life communicative exchange. Further lending support to the outcome of this study, Brown (1994) submits that students gain communicative competence when they use the target language productively and receptively in unrehearsed contexts under the guidance of the teacher. The outcome of this study underscores the relevance of the interactive potential of SRS in ESL classroom.

That listening skills contributed significantly to the prediction of the SRS group's communicative competence is indicative that the SRS technology is a useful tool in arousing and sustaining pupils' interest and attention in the classroom. Probably pupils' listening skills increased while SRS was used in the class in anticipation of the teacher's questions which were to be displayed on the projection screen. Additionally, perhaps pupils in the SRS group paid more attention to the teacher's explanation and peers' contributions during the peer or group work in order to gain more understanding of the subject matter and make useful contributions in the class.

\section{Conclusion}

One of the greatest challenges in English language teaching in Nigerian schools is the teachers' inability to take decisive decisions about what strategy or strategies to explore in order to foster learners' active engagement and optimum learning gains during instruction. The results of this study show clearly the need for English language teachers to rethink their teaching style. In particular, they need to consider points for and against a shift from the traditional classroom lecturestyle delivery to adopting the use of interactive technologies, such as SRS. Such a change becomes necessary if the teacher is to be able to initiate dialogue and discussion, as well as meaningful interaction in the class, in order to improve learning outcomes. Additionally, to determine a second language learners' progression in language acquisition, ESL teachers should make efforts towards measuring second language (L2) learners' communicative competence by first assessing their listening and speaking skills. In order to encourage easy and frequent use of English language among L2 learners, ESL teachers and other stakeholders in education from countries where English is adopted as the second language and the medium of instruction in schools, should encourage the adoption and effective integration of SRS into the educational system at all levels. 


\section{References}

Adegbile, J. A., \& Alabi, O. F. (2005). Proficiency and communicative competence in L2: Implications for teachers and learners. International Journal of African \& African American Studies, 4(2), 31 - 37.

Ajayi, L. (2002) Newspaper as enrichment material for enhancing students' performance in English. In L. Adebayo, I. Isiugo- Abanihe, \& I. N. Ohia (Eds.), Perspectives on applied linguistics in languages and literature (pp. 66 -88). Ibadan: Stirring-Horden.

Ariyo, K. S. (2010). A study of language learners strategies adopted by Nigerian students. Pakistan Journal of Social Sciences, 7(6), 433 - 436.

Bachman, L., \& Bachman, C. (2011). A study of classroom response system clickers: Increasing student engagement and performance in a large undergraduate lecture class on architectural research. Journal of Interactive Learning Research, 22(1), 5 - 21.

Bergtrom, G. (2006). Clicker sets as learning objects. Interdisciplinary Journal of Knowledge and Learning Objects, 2, 105-110. Retrieved from http://www.ijello.org/Volume2/v2p105-110Bergtrom.pdf

Boyer, E. L. (1998). The Boyer commission on educating undergraduates in the research university, reinventing undergraduate education: A blueprint for America's research universities. New York: Stony Brook.

Bransford, J. D., Brown, A. L., \& Cocking, R. R. (2000). How people learn: Brain, mind, experience, and school. Washington, DC: National Academy Press.

Brown, H. D. (1994). Principles of language learning and teaching. New Jersey: Prentice Hall Regents.

Cain, J., \& Robinson, E. (2008). A primer on audience response systems: Current applications and future considerations. American Journal of Pharmaceutical Education, 72, 1- 6.

Caldwell. J. E. (2007). Clickers in the large classroom: Current research and best-practice tips. CBE-Life Science Education, 6, 9 -19.

Camey, J. P., Gray, G. T., \& Wert-Gray, S. (2008). Evaluating the impact of student response systems on student performance. Journal for Advancement of Marketing Education, 13-17.

Canary, D. J. \& Cody, M. J. (2000): Interpersonal communication: A goals-based approach. New York: Saint Martin's Press.

Chickering, A. W., \& Gamson, Z. F. (1987). Seven principles for good practice in undergraduate education. Retrieved from http://www.economicsnetwork.ac.uk/handbook/ugresearch/5

Collins, L. J. (2007). Livening up the classroom: Using audience response systems to promote active learning. Medical Reference Services Quarterly, 26(1), 81-88.

Cook, J. (2010). Longitudinal, educational design research investigation of the temporal nature of learning: Taking a Vygotskian approach. Journal of Interactive Media in Education, 1-20.

Crouch, C. H., \& Mazur, E. (2001). Peer instruction: Ten years of experience and results. American Journal of Physics, 69, 970 - 977.

Dale, E. (1969) Audiovisual methods in teaching ( $3^{\text {rd }}$ ed.). New York: The Dryden Press.

Dill, E. (2008). Do clickers improve library instruction? Lock in your answers now? The Journal of Academic Librarianship, 34(6), 527-529.

Draper, S., Cargill, J., \& Cutts, Q. (2002). Electronically enhanced classroom interaction. Australasian Journal of Educational Technology, 18(1), 13-23.

Duncan D., (2006), Clickers: A new teaching aid with exceptional promise. Astronomy Education Review, $5,70-88$.

Fagen, A. P., Crouch, C. H., \& Mazur, E. (2002). Peer instruction: Results from a range of classrooms. The Physics Teacher, 40(4), 206-209

Freeman, S., \& Herron, J. C. (2007). Evolutionary analysis. Boston, MA: Pearson-Benjamin Cummings. 
Grimm, P. E., Soares, E., Agrawal, J., \& Law, S. (2007). Technology facilitated class participation in a principles of marketing course. Proceedings of the 2007 Australian and New Zealand Marketing Academy (ANZMAC) Conference, 3287-3292.

Hall, C. W. \& Swart, W. W. (2007). Utilising wireless polling devices to enhance classroom participation. Journal of Systemics, Cybernetics and Informatics, 5(3), 36-39.

Hancock, T. M. (2010). Use of audience response systems for summative assessment in large class. Australasian Journal of Educational Technology, 26(2), 226-237.

Hoffman, C., \& Goodwin, S. (2006). A clicker for your thought: Technology for active learning. New Library World, 107(9/10), $422-433$.

Holderied, A. C. (2011). Instructional design for the action: Employing interactive technologies and active learning exercise to enhance information literacy. Journal of Information Literacy, 5(1), 23 - 32.

Hudson, M., McGowan, L., \& Smith, C. (2011). Technology and learner motivation in library instruction: A study of personal response system. Indiana Libraries, 30(1), 20 - 27.

Johnson, K., \& Lillis, C. (2010). Clickers in the laboratory: Student thoughts and views. Interdisciplinary Journal of Information, Knowledge, and Management, 5, 139-151. Retrieved from http://www.ijikm.org/Volume5/IJIKMv5p139-151Johnson445.pdf

Johnson, M., \& Robson, D. (2008). Clickers, student engagement and performance in an introductory economics course: A cautionary tale. CHEER Virtual Edition, 20, 4-12.

Johnson, M., Robson, D., \& Van Scyoc, L. (2007). Paper or plastic: Evidence from a sample of clicker versus paper quizzes. Retrieved from http://www.uwosh.edu/programs/teachingforum/public html/?module=displaystory\&story id=693\&fo $\underline{\mathrm{rmat}=\mathrm{html}}$

Kamiya, M. (2006). The role of communicative competence in second language learning. Sophia Junior College Faculty Bulletin, 26, 63-87.

Kennedy, G. E., \& Cutts, Q. I. (2005). The association between students' use of an electronic voting system and their learning outcomes. Journal of Computer Assisted Learning, 21, 260-268.

Knight, J. K., \& Wood, W. B. (2005). Teaching more by lecturing less. Cell Biology Education, 4, 298 310.

Lantolf, J. P. (2000). Introducing sociocultural theory. In J. P. Lantolf (Ed.), Sociocultural theory and second language learning. UK: Oxford University Press.

Latessa, R., \& Mouw, D. (2005). Use of audience response system to augment interactive learning. Family Medicine, 37(1), 12-14.

Le, H. (2003). What does a more knowledgeable peer mean? A sociocultural analysis of group interaction in a Vietnamese classroom. Paper presented at the NZARE/AARE Joint Conference, Auckland, December 2003. Retrieved from http://www.aare.edu.au/03pap/le03008.pdf

Lea, B. (2008). Clickers adoption in a small class setting. Decision Line, 39, 7-11. Retrieved from http://www.decisionsciences.org/decisionline/Vol39/39 4/dsi-dl39 4class.pdf

Mareno, N., Bremner, M., \& Emerson, C. (2010). The use of audience response systems in nursing education: Best practice guidelines. International Journal of Nursing Education Scholarship, 7(1), 1 - 17. doi:10.2202/1548-923X.2049

Marlow, D. W., Wash, P. D., Chapman, J. M., \& Dale, T. M. (2009). Electric engagement: The use of classroom response technology in four disciplines. Currents in Teaching and Learning, 2(1), 17-27. Retrieved from http://www.worcester.edu/Currents/Archives/Volume_2_Number_1/CURRENTSV2N1MarlowetalP17 .pdf

Marmolejo, E. K., Wilder, D. A., \& Bradley, L. (2004). A preliminary analysis of the effects of response cards on student performance and participation in an upper division university course. Journal of Applied Behavior Analysis, 37, 405- 410. doi: 10.1901/jaba.2004.37-405 
Martyn, M. (2007). Clickers in the classroom: An active learning approach. Educause Quarterly, 2, 71-74.

Mateo, Z. F. (2010, July). Creating active learning in a large introductory statistics class using Clicker technology. In C. Reading (Ed.), Data and context in statistics education: Towards an evidence-based society. Proceedings of the 8th International Conference on Teaching Statistics, Ljubljana, Slovenia. Retrieved from http://www.stat.auckland.ac.nz/ iase/publications/icots8/ICOTS8_9E4_MATEO.pdf

Meedzan, N., \& Fisher, K. (2009). Clickers in nursing education: An active learning tool in the classroom. Online Journal of Nursing Informatics, 13 (2). Retrieved from http://144.216.1.72/uploadedFiles/academics/cte/Meedzan_Fisher.pdf

Mintzes, J. J., \& Leonard, W. H. (2006). Handbook of college science teaching. Arlington, VA: NSTA Press.

Mollborn, S., \& Hoekstra, A. (2010). A meeting of minds: Using clickers for critical thinking and discussion in large sociology classes. Teaching Sociology, 38(1), 18-27. doi: 10.1177/0092055X09353890

Moore, L. J. (2007). Ethical and organisational tensions for work-based learners. Journal of Workplace Learning. 19(3), 161-172. doi: 10.1108/13665620710735639

Morales, L. (2011). Can the use of clickers or continuous assessment motivate critical thinking? A case based on corporate finance students. Higher Learning Research Communications, 1(1), 33 - 42.

National Survey of Student Engagement. (2006). Engaged learning: Fostering success for all students. Retrieved from http://nsse.iub.edu/nsse_2006_annual_report/docs/nsse_2006_annual_report.pdf

O' Donoghue, M., \& O'Steen, B. (2007). Clicking on or off? Lecturers' rationale for using student response systems. Paper presented at the Australasian Society for Computers in Learning in Tertiary Education (ASCILITE) conference. December, 2007, Singapore.

Okoro, D.C.U. (2000). Basic education-emerging issues, challenges and constraints in the state of education in Nigeria. Abuja, Nigeria: UNESCO.

Oluwole, D. A. (2008). The impact of mother tongue on students' achievement in English language in junior secondary certificate examination in western Nigeria. Journal of Social Science, 17(1), 41 - 49.

Onukaogu, A. E. (2002). Developing effective reading skills. In A. Mansaray \& I. O. Osokoya (Eds.), Curriculum development at the turn of the century: Nigerian experience (pp. 25 -39). Ibadan: University of Ibadan.

Petersohn, B. (2008). Classroom performance systems, library instruction and instructional design: A pilot study. Libraries and the Academy, 313-324.

Patterson, B., Kilpatrick, J., \& Woebkenberg, E. (2010). Evidence for teaching practice: The impact of clickers in a large classroom. Nurse Education Today, 30, 603 - 607.

Phan, H. P. (2009). Future time perspective in sociocultural contexts: A discussion paper. Electronic Journal of Research in Educational Psychology, 7(2), 761-778.

Powers, D. E. (2010). The case for a comprehensive, four skills assessment of English language proficiency. $R \& D$ Connections, No. 14. Princeton, NJ: Educational Testing Service. Retrieved from http://www.ets.org/Media/Research/pdf/TC-10-12.pdf

Rankin, E., \& Hoass, D. J. (2001). Teaching note: Does the use of computer generated slide presentations in the classroom affect student performance and interest? Eastern Economic Journal, 27(3), 355 - 366.

Reay, N. W., Li, B., \& Bao, L. (2008). Testing new voting machine technology. American Journal of Physics, 76(2),171-178. Retrieved from http://www.missouristate.edu/assets/fctl/AJP 2008_2 171VM2.pdf

Ribbens, E. (2007). Why I like personal response systems. Journal of College Science Teaching, 3 (2), 6062.

Safranj, J. (2009). Students' communicative competence. Zbornik Instituta za pedagoska istrazivanja, 4l(1), 180 - 194. Retrieved from http://www.doiserbia.nb.rs/img/doi/0579-6431/2009/057964310901180S.pdf 
Schackow, T., Chavez, M., Loya, L., \& Friedman, M. (2004). Audience response system: Effect on learning in family medicine residents. Family Medicine, 36, 496-504. Retrieved from http://www.stfm.org/fmhub/fm2004/July/T.496.pdf

Sessoms, D. (2008). Interactive instruction: Creating interactive learning environments through tomorrow's teachers. International Journal of Technology in Teaching and Learning, 4(2), 86 - 96. Retrieved from http://www.sicet.org/journals/ijttl/issue0802/4_2_1_Sessoms.pdf

Shaver, M. P. (2010). Using low-tech interactions in the chemistry classroom to engage students in active learning. Journal of Chemical Education, 87, 1320-1323. doi: 10.1021/ed900017j

Stowell, J. R., \& Nelson, J. M. (2007). Benefits of electronic audience response systems on student participation, learning and emotion. Teaching of Psychology, 34, 253-258. doi:10.1080/00986280701700391

Surgenor, P. W. G. (2010). Luddites and learning theories: Lessons from a flawed clicker project. Paper presented at the International Conference on Engaging Pedagogy, Maynooth, Ireland. September, 2010.

Swan, K., Kratcoski, A., Schenker, J., \& Van-'tHooft, M. (2010, July). Interactive whiteboard and students' achievement. Paper presented at the World Conference on Educational Multimedia, Hypermedia and Telecommunications, Vienna.

Tagg, J. (2003). The learning paradigm college. Boston: Anker Publishing

Turuk, M. C. (2008). The relevance and implication of Vygotsky's sociocultural theory in the second language classroom. Annual Review of Education, Communication and language Sciences, 5, 244 - 262. Retrieved from http://research.ncl.ac.uk/ARECLS/volume_5/turuk_vol5.pdf

Ulbig, S. G., \& Notman, F. (2010, November). Is class appreciation just a click away? Using student response system technology to enhance shy students' introductory American government experience. Paper presented the Annual Meeting of the Northeastern Political Science Association, Boston, USA.

Uso-Juan, E., \& Martinez-Flor, A. (2008). Teaching intercultural communicative competence through the four skills. In Revista Alicantina de Estudios Ingleses, 21, 157-170.

Vygotsky, L. S. (1978). Mind in society: The development of higher psychological processes. Cambridge: Harvard University.

Vygotsky, L. S. (1986). Thought and language. Cambridge: The MIT.

Vygotsky, L. S. (1993). The fundamentals of defectology (abnormal psychology and learning disabilities). In R. W. Rieber \& A. S. Carton (Eds.), The collected works of L. S. Vygotsky, (Vol. 2). New York: Plenum Press.

Wood, W. B. (2004). Clickers: A teaching gimmick that works. Developmental Cell, 6(6), 796-798.

Yoder, J. D., \& Hochevar, C. M. (2005). Encouraging active learning can improve students' performance on examinations. Teaching of Psychology, 32, 91- 95.

Yusuf, H. O., \& Enesi, A. O. (2011). Teaching reading across the classroom. Theory and Practice in Language Studies, 1(11), 1581-1585. doi:10.4304/tpls.1.11.1581-1585

\section{Biography}

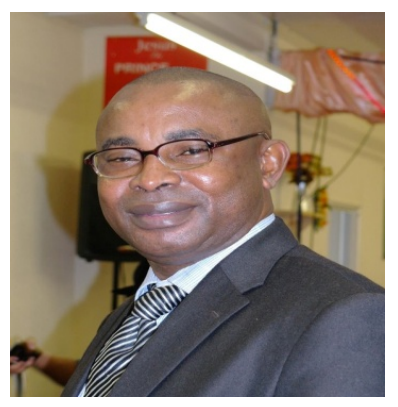

Alaba Olaoluwakotansibe Agbatogun is a $\mathrm{PhD}$ student at The Moray House of School of Education, The University of Edinburgh,United Kingdom. He holds a Masters degree in Educational Technology from the University of Lagos, Nigeria. He lectures in the Department of Curriculum Studies and Instructional Technology, Olabisi Onabanjo University, Nigeria. His areas of interest include gender issues in learning technology, e-learning, technology and interactivity in education. He has authored and co-authored a number of research articles in peerreviewed journals. 